\title{
Pengaruh Jenis Bahan Campuran dalam Re-Kompos Residu Teh Kompos Terhadap Pertumbuhan dan Hasil Tanaman Bayam (Amaranthus tricolor, L.)
}

\author{
Eduardus Y. Neonbeni ${ }^{\mathrm{a}}$, Maria Kornelia Oki ${ }^{\mathrm{b}}$ \\ ${ }^{a}$ Fakultas Pertanian, Universitas Timor, Kefamenanu, TTU - NTT, Indonesia, email: ambeni02@ gmail.com \\ ${ }^{b}$ Fakultas Pertanian, Universitas Timor, Kefamenanu, TTU - NTT, Indonesia, email: merioki03@ gmail.com
}

\section{Article Info}

Article history:

Accepted 20 September 2019

DOI:

https://doi.org/10.32938/sc.v4i01.767

\section{Keywords:}

Biochar

Hijauan Kirinyuh

Pengomposan kembali

Residu teh kompos
Received 19 Juni 2019

Received in revised form 21 Agustus 2019

Amaranthus tricolor $\mathrm{L}$

\section{Abstrak}

Residu kompos merupakan limbah bahan organik yang dapat dimanfaatkan kembali sebagai pupuk organik melalui pengomposan kembali menggunakan campuran beberapa bahan organik. Suatu percobaan pot telah dilakukan dengan menggunakan bahan campuran berupa hijauan kirinyuh dan biochar dalam pengomposan kembali residu teh kompos dalam pemanfaatan sebagai media pertumbuhan bayam cabut (Amaranthus tricolor L.) dengan sistem tabela. Penelitian ini bertujuan untuk mengetahui dampak pertumbuhan dan produksi bayam yang diberi kompos yang telah dikomposkan ulang (re-kompos). Penelitian ini dilaksanakan di kebun percobaan Fakultas Pertanian Universitas Timor, pada bulan Maret-April 2019. Rancangan yang digunakan adalah Rancangan Acak Lengkap (RAL) faktorial dua faktor dengan 3 kali ulangan. Faktor pertama perlakuan persentase komposisi campuran biochar yang terdiri atas kontrol, residu teh kompos + biochar $2,5 \%$, residu teh kompos + biochar $5 \%$ dan residu teh kompos + biochar $10 \%$. Faktor kedua berupa persentase komposisi hijauan kirinyu yakni kontrol, residu teh kompos + kirinyuh 2,5\%, residu teh kompos + kirinyuh $5 \%$ dan residu teh + kirinyuh $10 \%$. Hasil sidik ragam anova menunjukkan bahwa terjadi interaksi pemberian re-kompos biochar $10 \%$ dan rekompos kirinyuh $10 \%$ berpengaruh terhadap tinggi tanaman 28 HST $(15,42 \mathrm{~cm})$, diameter batang 28 HST $(0,54)$, jumlah daun $21(6,50$ helai) dan 28 HST $(9,17$ helai), berat segar tanaman $(19,22 \mathrm{~g})$, berat segar trubus $(16,81 \mathrm{~g})$ dan panjang akar tanaman bayam $(13,17 \mathrm{~cm})$. Kombinasi pemberian re-kompos biochar $10 \%$ dan re-kompos kirinyu $10 \%$ merupakan perlakuan terbaik, berbeda nyata dengan perlakuan lainnya.

\section{Pendahuluan}

Tanaman Bayam merupakan tanaman yang sangat dibutuhkan masyarakat mengingat fungsinya sebagai pemenuh kebutuhan gizi masyarakat karena mengandung zat gizi antara lain: Protein, Karbohidrat, Lemak, Zat Bes Vitamin A, B, C serta Serat (Rukmana, 2010) sehingga perlu dilakukan peningkatan produksi untuk mencukupi kebutuhan gizi masyarakat Peningkatan produksi Bayam dapat dilakukan dengan cara penambahan unsur hara pada lahan pertanian. Unsur hara dapat diperoleh dengan cara pemupukan. Pemupukan merupakan suatu usaha penambahan unsur hara kedalam tanah yang dapat meningkatkan kesuburan dan produksi tanaman. Teh kompos adalah ekstrak dari kompos. Residu dari teh kompos adalah limbah pertanian yang bersumber dari ekstrak teh kompos dan selama ini pemanfaatannya dalam bidang pertanian belum memadai terutama dalam penggunaannya. Untuk mengetahui efek dan pengaruhnya maka residu dari ekstrak teh kompos dapa dibuat menjadi bahan dasar yang dikomposkan ulang dengan ditambahkan hijauan dan biochar dengan level yang berbeda. Kirinyuh adalah salah satu tanaman hutan yang cukup terkenal dan tersebar di pulau Timor dengan sebutan Sufmuti. Hasil eksplorasi dan penelitian menunjukkan bahwa tumbuhan Kirinyuh mempunyai potensi sebagai biofertilizer dan bioinsektisida obatobatan serta bioherbisida (Bete, 2018). Tumbuhan Kirinyu juga mempunyai kandungan hara $\mathrm{N}(2,65 \%), \mathrm{P}(0,53 \%), \mathrm{K}(1,9 \%)$ sehingga biomasa ini dapat dijadikan sebagai pupuk organik yang potensial (Yuliandry. 2008.).

Biochar merupakan salah satu bentuk aplikasi teknologi yang memanfaatkan bahan hasil limbah yang tersedia di alam untuk dimanfaatkan sebagai media pembenah tanah, dalam usaha meningkatkan nilai produksi tanaman. Lehmann dan Joseph, (2009) mengatakan bahwa biochar merupakan bahan yang memiliki kandungan karbon tinggi yang berasal dari biomasa kayu atau sisa hasil pengolahan tanaman yang dibakar di suatu wadah dengan sediki atau tanpa udara. Pemberian biochar kedalam tanah dapat meningkatkan kesubururan tanah karena biochar mampu mengikat karbon dan menyediakan habitat yang baik bagi kehidupan mikroorganisme tanah. Penelitian Asa (2017) membuktikan biochar $10 \mathrm{t} /$ ha dapat meningkatkan daya hantar listrik, $\mathrm{pH}$ tanah dan meningkatkan pertumbuhan (tinggi, diameter batang dan jumlah daun) serta hasil tanaman, berupa berat segar tanaman dan berat segar trubus. Selain itu, dalam penelitian tersebut juga digunakan residu teh kompos sebagai pengkaya bagi biochar, namun terjadi persoalan pada pertumbuhan tanaman yang diduga akibat proses dekomposisi residu teh kompos setelah diaplikasikan ke dalam media tanam bersama biochar. Oleh karena itu disarankan agar residu teh kompos yang digunakan sebaiknya dikomposkan terlebih dahulu sebelum digunakan.

Berdasarkan uraian di atas, untuk meningkatkan produksi dan hasi bayam maka perlu dilakukan penelitian untuk membuktikan "Pengaruh Jenis Bahan Campuran dalam Rekompos Residu Teh Kompos Terhadap Pertumbuhan dan Hasil Tanaman Bayam (Amaranthus Tricolor, L.)". Penelitian ini bertujuan untuk mengetahui dampak pertumbuhan dan produksi bayam pada bahan campuran dalam rekompos residu teh kompos yang dikomposkan ulang dengan menggunakan biochar dan hijauan dengan level yang berbeda.

\section{Metode}

Penelitian ini dilaksanakan pada bulan Maret-April 2019 di kebun percobaan Fakultas Pertanian Universitas Timor, Kelurahan Sasi, Kecamatan Kota Kefamenanu, Kabupaten TTU menggunakan Rancangan Acak Lengkap (RAL) faktorial yang terdiri dari dua faktor perlakuan, yaitu: faktor pertama terdiri dari 4 aras, yaitu: pengomposan bahan ampas teh kompos tanpa biochar sebagai kontrol (B0), Biochar 2,5\% (B1), Biochar $5 \%$ (B2) dan ampas teh kompos + Biochar $10 \%$ (B3). Faktor kedua adalah komposisi Kirinyuh yang ditambahkan dalam pengomposan yang terdiri dari 4 aras yaitu: tanpa Kerinyuh atau kontrol (K0), Kerinyu 2,5\% (K1), Kerinyu 5\% (K2) dan Kerinyu $10 \%$ (K3). Pelaksana penelitian diawali dengan persiapan benih, persiapan media tanam, persiapan pupuk, pemupukan, penanaman, perawatan tanaman yang meliputi, penyulaman, penyiraman, penyiangan, panen dan pengamatan yang meliputi kondisi lingkungan tanam, pertumbuhan tanaman dan hasil yakni suhu tanah, daya hantar listrik tanah, $\mathrm{pH}$ tanah, kadar lengas tanah, berat volume, tinggi tanaman, diameter batang, jumlah daun luas daun, berat segar tanaman, berat kering tanaman, berat segar trubus, berat kering trubus, panjang akar, berat segar akar, berat kering akar, ratio tajuk akar dan indeks panen.Analisis statistik pada penelitian ini menggunakan perangkat lunak (software) SAS® for Windows 9.1 (SAS Institute Inc., USA). Data diuji lanjut pada tingkat nyata $(\alpha)$ $5 \%$ menurut uji DMRT untuk mengetahui adanya interaksi antara kompos biochar dan kompos kirinyuh.

\section{Hasil dan Pembahasan \\ 3.1. Hasil Suhu Tanah}

Hasil sidik ragam (anova) menunjukkan tidak terjadi interaksi antara perlakuan kompos biochar dan kompos kirinyu terhadap suhu tanah -1 dan 28 HST. Hasil penelitian menunjukkan bahwa kompos biochar tidak menunjukkan pengaruh yang nyata terhadap suhu tanah pada waktu pengamatan -1 dan 28 HST. Data tabel 1 menunjukkan suhu tanah tertinggi -1 dan 28 HST terdapat pada perlakuan tanpa kompos biochar dan suhu tanah terendah -1 dan 28 HST terdapat pada perlakuan kompos biochar $10 \%$. Pada hasil kompos Kirinyu juga tidak menunjukkan pengaruh yang nyata antar aras perlakuan. Hasil penelitian menunjukkan bahwa pada pengamatan -1 dan 28 HST tertinggi terdapat pada perlakuan tanpa kompos kirinyu dan suhu tanah terendah terdapat pada perlakuan kompos kirinyu $10 \%$

\section{pH Tanah}

Hasil sidik ragam (Anova) menunjukkan tidak terjadi interaksi antara perlakuan kompos biochar dan kompos Kirinyu terhadap $\mathrm{pH}$ tanah -1 dan 28 HST. Hasil penelitian menunjukkan bahwa kompos biochar tidak menunjukkan pengaruh yang nyata terhadap $\mathrm{pH}$ tanah pada waktu pengamatan -1 dan 28 HST. Data tabel 2 menunjukkan pH tanah -1 dan 28 HST yang mendekati netral terdapat pada perlakuan kompos biochar $10 \%$. Kompos Kirinyu juga tidak menunjukkan pengaruh yang nyata antar aras perlakuan. Hasil penelitian menunjukkan bahwa pada pengamatan -1 dan 28 HST mendekati netral terdapat pada perlakuan $10 \%$

\section{Daya Hantar Listrik}

Hasil sidik ragam (Anova) menunjukkan tidak terjadi interaksi antara perlakuan kompos biochar dan kompos Kirinyuh terhadap daya hantar listrik tanah -1 dan 28 HST. Hasil penelitian menunjukkan bahwa kompos biochar menunjukkan pengaruh yang nyata terhadap daya hantar listrik tanah pada waktu pengamatan -1 dan 28 HST. Data tabel 3 menunjukkan daya hantar listrik tanah tertinggi -1 dan 28 HST terdapat pada perlakuan kompos biochar $10 \%$ dan daya hantar listrik tanah terendah -1 dan 28 HST terdapat pada perlakuan tanpa kompos biochar. Kompos kirinyuh juga menunjukkan pengaruh yang nyata antar aras perlakuan. Hasil penelitian menunjukkan bahwa pada pengamatan -1 dan 28 HST tertinggi terdapat pada perlakuan $10 \%$ dan daya hantar listrik tanah terendah terdapat pada perlakuan kompos Kirinyuh 10 $\%$. 
Tabel 1. Suhu Tanah $\left({ }^{\circ} \mathrm{C}\right)$

\begin{tabular}{|c|c|c|c|c|c|c|}
\hline \multirow{2}{*}{$\begin{array}{l}\text { Waktu } \\
\text { Pengamatan } \\
\text { (HST) }\end{array}$} & \multirow{2}{*}{$\begin{array}{c}\text { Kompos } \\
\text { Biochar }(\%)\end{array}$} & \multicolumn{4}{|c|}{ Kompos Kirinyuh (\%) } & \multirow[b]{2}{*}{ Rerata } \\
\hline & & 0 & 2,5 & 5 & 10 & \\
\hline \multirow{5}{*}{-1} & 0 & 42,2 & 42,0 & 41,4 & 40,4 & $41,5^{\mathrm{a}}$ \\
\hline & 2,5 & 42,6 & 41,5 & 41,1 & 40,3 & $41,4^{\mathrm{a}}$ \\
\hline & 5 & 42,0 & 41,2 & 40,6 & 40,6 & $41,1^{\mathrm{a}}$ \\
\hline & 10 & 41,7 & 40,1 & 41,1 & 40,1 & $40,7^{\mathrm{a}}$ \\
\hline & Rerata & $42,1^{\mathrm{a}}$ & $41,2^{\mathrm{ab}}$ & $41,1^{\mathrm{b}}$ & $40,3^{\mathrm{b}}$ & $(-)$ \\
\hline \multirow{5}{*}{28} & 0 & 32,3 & 30,9 & 31,4 & 30,6 & $31,3^{\mathrm{a}}$ \\
\hline & 2,5 & 30,5 & 30,3 & 31,5 & 30,2 & $30,6^{\mathrm{ab}}$ \\
\hline & 5 & 30,2 & 30,6 & 30,3 & 31,1 & $30,6^{\mathrm{ab}}$ \\
\hline & 10 & 30,2 & 30,4 & 30,2 & 30,0 & $30,2^{\mathrm{b}}$ \\
\hline & Rerata & $30,8^{\mathrm{a}}$ & $30,6^{\mathrm{a}}$ & $30,9^{\mathrm{a}}$ & $30,5^{\mathrm{a}}$ & $(-)$ \\
\hline
\end{tabular}

Keterangan: Angka pada baris dan kolom yang sama diikuti huruf sama menunjukkan tidak berbeda pada tingkat nyata ( $\alpha) 5 \%$ menurut uji DMRT. (-) tidak terjadi interaksi antar faktor.

\begin{tabular}{|c|c|c|c|c|c|c|}
\hline \multirow{2}{*}{$\begin{array}{c}\text { Waktu } \\
\text { Pengamatan } \\
\text { (HST) }\end{array}$} & \multirow{2}{*}{$\begin{array}{c}\text { Kompos } \\
\text { Biochar }(\%)\end{array}$} & \multicolumn{4}{|c|}{ Kompos Kirinyuh (\%) } & \multirow[b]{2}{*}{ Rerata } \\
\hline & & 0 & 2,5 & 5 & 10 & \\
\hline \multirow{5}{*}{-1} & 0 & 6,02 & 6,02 & 6,04 & 6,07 & $6,04^{\mathrm{a}}$ \\
\hline & 2,5 & 6,04 & 5,99 & 6,10 & 6,08 & $6,05^{\mathrm{a}}$ \\
\hline & 5 & 6,10 & 6,06 & 6,03 & 6,07 & $6,07^{\mathrm{a}}$ \\
\hline & 10 & 6,10 & 6,09 & 6,12 & 6,14 & $6,11^{\mathrm{a}}$ \\
\hline & Rerata & $6,06^{\mathrm{a}}$ & $6,04^{\mathrm{a}}$ & $6,07^{\mathrm{a}}$ & $6,09^{a}$ & $(-)$ \\
\hline \multirow{5}{*}{28} & 0 & 6,21 & 6,25 & 6,24 & 6,23 & $6,24^{b}$ \\
\hline & 2,5 & 6,26 & 6,24 & 6,27 & 6,26 & $6,26^{a b}$ \\
\hline & 5 & 6,23 & 6,24 & 6,31 & 6,31 & $6,27^{\mathrm{ab}}$ \\
\hline & 10 & 6,28 & 6,29 & 6,31 & 6,35 & $6,31^{\mathrm{a}}$ \\
\hline & Rerata & $6,25^{a}$ & $6,26^{\mathrm{a}}$ & $6,28^{a}$ & $6,29^{a}$ & $(-)$ \\
\hline
\end{tabular}

Keterangan: Angka pada baris dan kolom yang sama diikuti huruf sama menunjukkan tidak berbeda pada tingkat nyata ( $\alpha$ ) $5 \%$ menurut uji DMRT. (-) tidak terjadi interaksi antar faktor

Tabel 3. Daya Hantar Listrik Tanah $(\mu / \mathrm{cm})$

\begin{tabular}{|c|c|c|c|c|c|c|}
\hline \multirow{2}{*}{$\begin{array}{c}\text { Waktu } \\
\text { Pengamatan } \\
\text { (HST) }\end{array}$} & \multirow{2}{*}{$\begin{array}{c}\text { Kompos } \\
\text { Biochar } \\
(\%)\end{array}$} & \multicolumn{4}{|c|}{ Kompos Kirinyuh (\%) } & \multirow[b]{2}{*}{ Rerata } \\
\hline & & 0 & 2,5 & 5 & 10 & \\
\hline \multirow{5}{*}{-1} & 0 & 234,67 & 282,00 & 351,00 & 399,67 & $316,83^{\mathrm{c}}$ \\
\hline & 2,5 & 245,33 & 288,67 & 347,67 & 450,00 & $332,92^{\mathrm{bc}}$ \\
\hline & 5 & 325,00 & 317,67 & 336,33 & 455,33 & $358,58^{b}$ \\
\hline & 10 & 352,33 & 337,00 & 454,33 & 458,33 & $400,50^{\mathrm{a}}$ \\
\hline & Rerata & $289,33^{\mathrm{c}}$ & $306,33^{c}$ & $372,33^{b}$ & $440,83^{a}$ & $(-)$ \\
\hline \multirow{5}{*}{28} & 0 & 347,00 & 349,00 & 366,67 & 468,67 & $382,83^{b}$ \\
\hline & 2,5 & 450,33 & 458,00 & 416,00 & 385,67 & $427,50^{b}$ \\
\hline & 5 & 411,00 & 383,67 & 484,67 & 450,67 & $432,50^{b}$ \\
\hline & 10 & 519,67 & 553,00 & 482,33 & 601,67 & $539,17^{\mathrm{a}}$ \\
\hline & Rerata & $432,00^{\mathrm{a}}$ & $435,92^{\mathrm{a}}$ & $437,42^{a}$ & $476,67^{a}$ & $(-)$ \\
\hline
\end{tabular}

Keterangan: Angka pada baris dan kolom yang sama diikuti huruf tidak sama menunjukkan berbeda pada tingkat nyata $(\alpha)$ 5\% menurut uji DMRT. (-) tidak terjadi interaksi antar faktor.

\section{Kadar Lengas Tanah}

Hasil sidik ragam (Anova) menunjukkan tidak terjadi interaksi antara perlakuan kompos biochar dan kompos Kirinyuh terhadap daya kadar lengas tanah -1 dan 28 HST. Hasil penelitian menunjukkan bahwa kompos biochar tidak berpengaruh nyata terhadap kadar lengas tanah pada waktu pengamatan -1 dan 28 HST. Data tabel 4 menunjukkan kadar lengas tanah tertinggi - 1 dan 28 HST terdapat pada perlakuan kompos biochar $10 \%$ dan kadar lengas tanah terendah -1 dan 28 HST terdapat pada perlakuan tanpa kompos biochar. Kompos Kirinyuh juga tidak menunjukkan pengaruh yang nyata antar aras perlakuan. Hasil penelitian menunjukkan bahwa pada pengamatan -1 dan 28 HST tertinggi terdapat pada perlakuan $10 \%$ dan kadar lengas tanah terendah terdapat pada perlakuan tanpa kompos Kirinyuh.

\section{Berat Volume Tanah}

Hasil sidik ragam (Anova) menunjukkan tidak terjadi interaksi antara perlakuan kompos biochar dan kompos Kirinyu terhadap berat volume tanah -1 dan 28 HST. Hasil penelitian menunjukkan bahwa kompos biochar tidak berpengaruh nyata terhadap berat volume tanah pada waktu pengamatan -1 dan 28 HST. Data tabel 5 menunjukkan berat volume tanah terendah -1 dan 28 HST terdapat pada perlakuan kompos biochar $10 \%$ dan berat volume tanah tertinggi -1 dan 28 HST terdapat pada perlakuan tanpa kompos biochar. Kompos kirinyuh juga tidak menunjukkan pengaruh yang nyata antar aras perlakuan. Hasil penelitian menunjukkan bahwa berat volume tanah pada pengamatan -1 dan 28 HST terendah terdapat pada perlakuan $10 \%$ dan berat volume tanah tertinggi terdapat pada perlakuan tanpa kompos Kirinyuh.
Tabel 4.Kadar Lengas Tanah (\%)

\begin{tabular}{ccccccc}
\hline \multirow{2}{*}{$\begin{array}{c}\text { Waktu } \\
\text { Pengamatan } \\
\text { (HST) }\end{array}$} & $\begin{array}{c}\text { Kompos } \\
\text { Biochar (\%) }\end{array}$ & 0 & 2,5 & 5 & 10 & Rerata \\
\cline { 3 - 6 } & 0 & 37,71 & 39,23 & 39,88 & 41,53 & $39,59^{\mathrm{a}}$ \\
& 2,5 & 37,19 & 40,46 & 42,05 & 38,97 & $39,67^{\mathrm{a}}$ \\
-1 & 5 & 35,56 & 41,31 & 42,59 & 44,37 & $40,96^{\mathrm{a}}$ \\
& 10 & 42,91 & 44,78 & 42,34 & 42,66 & $43,17^{\mathrm{a}}$ \\
\hline & Rerata & $38,34^{\mathrm{a}}$ & $41,44^{\mathrm{a}}$ & $41,71^{\mathrm{a}}$ & $41,88^{\mathrm{a}}$ & $(-)$ \\
\hline \multirow{4}{*}{28} & 0 & 31,31 & 30,54 & 28,27 & 31,42 & $30,38^{\mathrm{a}}$ \\
& 2,5 & 32,03 & 34,34 & 32,41 & 30,99 & $32,44^{\mathrm{a}}$ \\
& 5 & 23,99 & 29,91 & 36,60 & 39,72 & $32,56^{\mathrm{a}}$ \\
& 10 & 33,28 & 34,76 & 35,88 & 31,32 & $33,81^{\mathrm{a}}$ \\
\hline & Rerata & $30,15^{\mathrm{a}}$ & $32,39^{\mathrm{a}}$ & $33,29^{\mathrm{a}}$ & $33,36^{\mathrm{a}}$ & $(-)$ \\
\hline
\end{tabular}

Keterangan: Angka pada baris dan kolom yang sama diikuti huruf sama menunjukkan tidak berbeda pada tingkat nyata (a) 5\% menurut uji DMRT. (-) tidak terjadi interaksi antar faktor.

$\underline{\text { Tabel 5. Berat Volume Tanah }\left(\mathrm{g} / \mathrm{cm}^{3}\right)}$

\begin{tabular}{ccccccc}
\hline $\begin{array}{c}\text { Waktu } \\
\text { Pengamatan } \\
\text { (HST) }\end{array}$ & $\begin{array}{c}\text { Kompos } \\
\text { Biochar }(\%)\end{array}$ & 0 & 2,5 & 5 & 10 & Rerata \\
\cline { 3 - 6 } & 0 & 1,64 & 1,43 & 1,40 & 1,47 & $1,48^{\mathrm{a}}$ \\
& 2,5 & 1,31 & 1,78 & 1,33 & 1,46 & $1,47^{\mathrm{a}}$ \\
-1 & 5 & 1,48 & 1,49 & 1,39 & 1,44 & $1,45^{\mathrm{a}}$ \\
& 10 & 1,59 & 1,11 & 1,59 & 1,19 & $1,37^{\mathrm{a}}$ \\
\hline & Rerata & $1,50^{\mathrm{a}}$ & $1,45^{\mathrm{a}}$ & $1,43^{\mathrm{a}}$ & $1,39^{\mathrm{a}}$ & $(-)$ \\
\hline & 0 & 1,46 & 1,39 & 1,06 & 1,23 & $1,29^{\mathrm{a}}$ \\
& 2,5 & 1,39 & 1,27 & 1,35 & 0,97 & $1,25^{\mathrm{a}}$ \\
& 5 & 1,38 & 1,35 & 1,30 & 0,89 & $1,23^{\mathrm{a}}$ \\
& 10 & 1,14 & 0,85 & 0,96 & 0,90 & $0,96^{\mathrm{b}}$ \\
\hline & Rerata & $1,34^{\mathrm{a}}$ & $1,22^{\mathrm{ab}}$ & $1,17^{\mathrm{ab}}$ & $1,00^{\mathrm{b}}$ & $(-)$ \\
\hline
\end{tabular}

Keterangan: Angka pada baris dan kolom yang sama diikuti huruf sama menunjukkan tidak berbeda pada tingkat nyata (a) 5\% menurut uji DMRT. (-) tidak terjadi interaksi antar faktor.

\section{Tinggi Tanaman}

Tinggi tanaman terus bertambah selama waktu penelitian. Hasil sidik ragam (Anova) menunjukkan bahwa kompos biochar $10 \%$ dan kompos Kirinyuh $10 \%$ berinteraksi secara positif $(\mathrm{P}<0.05)$ dalam mempengaruhi tinggi tanaman pada pengamatan 28 HST. Hasil sidik ragam (Anova) menunjukkan tidak terjadi interaksi antara perlakuan kompos biochar dan kompos Kirinyuh terhadap tinggi tanaman 14 dan 21 HST. Hasil penelitian menunjukkan bahwa kompos biochar berpengaruh nyata terhadap tinggi tanaman pada waktu pengamatan 14 dan 21 HST. Data tabel 6 menunjukkan tinggi tanaman tertinggi 14 dan 21 HST pada perlakuan kompos biochar $10 \%$ cenderung meningkatkan tinggi tanaman. Kompos Kirinyuh juga menunjukkan pengaruh yang nyata antar aras perlakuan. Hasil penelitian menunjukkan bahwa tinggi tanaman pada pengamatan 14 dan 21 HST dengan pemberian kompos Kirinyuh $10 \%$ cenderung meningkatkan tinggi tanaman.

Tabel 6. Tinggi Tanaman (cm)

\begin{tabular}{|c|c|c|c|c|c|c|}
\hline \multirow{2}{*}{$\begin{array}{c}\text { Waktu } \\
\text { Pengamatan } \\
\text { (HST) }\end{array}$} & \multirow{2}{*}{$\begin{array}{c}\text { Kompos } \\
\text { Biochar } \\
(\%)\end{array}$} & \multicolumn{4}{|c|}{ Kompos Kirinyuh (\%) } & \multirow[b]{2}{*}{ Rerata } \\
\hline & & 0 & 2,5 & 5 & 10 & \\
\hline \multirow{5}{*}{14} & 0 & 1,05 & 1,17 & 1,35 & 2,78 & $1,59^{\mathrm{b}}$ \\
\hline & 2,5 & 1,15 & 1,60 & 1,72 & 2,17 & $1,66^{\mathrm{b}}$ \\
\hline & 5 & 1,45 & 1,80 & 1,97 & 2,03 & $1,81^{\mathrm{b}}$ \\
\hline & 10 & 1,65 & 2,23 & 1,95 & 3,12 & $2,24^{\mathrm{a}}$ \\
\hline & Rerata & $1,33^{\mathrm{b}}$ & $1,70^{\mathrm{b}}$ & $1,75^{\mathrm{b}}$ & $2,53^{\mathrm{a}}$ & $(-)$ \\
\hline \multirow{5}{*}{21} & 0 & 2,25 & 2,12 & 2,77 & 5,18 & $3,08^{\mathrm{c}}$ \\
\hline & 2,5 & 2,22 & 3,78 & 4,53 & 5,25 & $3,95^{\mathrm{b}}$ \\
\hline & 5 & 3,33 & 3,93 & 3,97 & 4,73 & $3,99^{b}$ \\
\hline & 10 & 3,97 & 5,50 & 4,37 & 7,08 & $5,23^{\mathrm{a}}$ \\
\hline & Rerata & $2,94^{\mathrm{c}}$ & $3,83^{\mathrm{b}}$ & $3,91^{\mathrm{b}}$ & $5,56^{\mathrm{a}}$ & $(-)$ \\
\hline \multirow{5}{*}{28} & 0 & $2,25^{\mathrm{h}}$ & $3,22^{\text {gh }}$ & $4,87^{\text {gf }}$ & $10,07^{\text {bcd }}$ & 5,10 \\
\hline & 2,5 & $3,75^{\text {gh }}$ & 7,35 def & $7,98^{\text {cde }}$ & $10,20^{\mathrm{bc}}$ & 7,32 \\
\hline & 5 & $6,88^{\text {ef }}$ & $8,03^{\text {cde }}$ & $8,18^{\text {bcde }}$ & $9,73^{b c d}$ & 8,21 \\
\hline & 10 & $8,08^{\text {cde }}$ & $10,83^{\mathrm{b}}$ & $8,67^{\text {bcde }}$ & $15,42^{\mathrm{a}}$ & 10,75 \\
\hline & Rerata & 5,24 & 7,36 & 7,43 & 11,35 & $(+)$ \\
\hline
\end{tabular}

Keterangan: Angka pada baris dan kolom yang sama diikuti huruf sama menunjukkan tidak berbeda pada tingkat nyata $(\alpha) 5 \%$ menurut uji DMRT. (-) tidak terjadi interaksi antar faktor. (+) tidak terjadi interaksi antar faktor.

\section{Diameter Batang}

Berdasarkan hasil sidik ragam (Anova) menunjukkan bahwa kompos biochar $10 \%$ dan kompos Kirinyuh $10 \%$ berinteraksi secara positif $(\mathrm{P}<0.05)$ dalam mempengaruhi diameter batang pada pengamatan 28 HST. Hasil sidik ragam (Anova) menunjukkan tidak terjadi interaksi antara perlakuan kompos biochar dan kompos Kirinyuh terhadap diameter batang 14 dan 21 HST. Hasil penelitian menunjukkan bahwa kompos biochar berpengaruh nyata terhadap diameter batang pada waktu pengamatan 14 dan 21 HST. Data tabel 7 menunjukkan diameter batang terbesar 14 dan 21 HST pada perlakuan kompos 
biochar $10 \%$ dan diameter batang terkecil terdapat pada tanpa kompos biochar. Kompos Kirinyuh juga menunjukkan pengaruh yang nyata antar aras perlakuan. Hasil penelitian menunjukkan bahwa tinggi tanaman pada pengamatan 14 dan 21 HST dengan pemberian kompos kirinyuh $10 \%$ cenderung meningkatkan diameter batang.

Tabel 7. Diameter Batang $(\mathrm{cm})$

\begin{tabular}{|c|c|c|c|c|c|c|}
\hline \multirow{2}{*}{$\begin{array}{c}\text { Waktu } \\
\text { Pengamatan } \\
\text { (HST) }\end{array}$} & \multirow{2}{*}{$\begin{array}{c}\text { Kompos } \\
\text { Biochar } \\
(\%)\end{array}$} & \multicolumn{4}{|c|}{ Kompos Kirinyuh (\%) } & \multirow[b]{2}{*}{ Rerata } \\
\hline & & 0 & 2,5 & 5 & 10 & \\
\hline \multirow{5}{*}{14} & 0 & 0,11 & 0,11 & 0,11 & 0,12 & $0,11^{\mathrm{b}}$ \\
\hline & 2,5 & 0,11 & 0,11 & 0,12 & 0,12 & $0,11^{\mathrm{b}}$ \\
\hline & 5 & 0,11 & 0,12 & 0,11 & 0,11 & $0,11^{a b}$ \\
\hline & 10 & 0,11 & 0,12 & 0,12 & 0,13 & $0,12^{\mathrm{a}}$ \\
\hline & Rerata & $0,11^{\mathrm{c}}$ & $0,11^{\mathrm{b}}$ & $0,12^{a b}$ & $0,12^{\mathrm{a}}$ & $(-)$ \\
\hline \multirow{5}{*}{21} & 0 & 0,13 & 0,18 & 0,21 & 0,29 & $0,20^{\mathrm{c}}$ \\
\hline & 2,5 & 0,20 & 0,25 & 0,26 & 0,28 & $0,25^{\mathrm{b}}$ \\
\hline & 5 & 0,24 & 0,24 & 0,25 & 0,26 & $0,25^{\mathrm{b}}$ \\
\hline & 10 & 0,25 & 0,32 & 0,29 & 0,36 & $0,30^{\mathrm{a}}$ \\
\hline & Rerata & $0,20^{\mathrm{c}}$ & $0,25^{\mathrm{b}}$ & $0,25^{\mathrm{b}}$ & $0,30^{\mathrm{a}}$ & $(-)$ \\
\hline \multirow{5}{*}{28} & 0 & $0,18^{\mathrm{h}}$ & $0,25^{\mathrm{gh}}$ & $0,01^{\text {gh }}$ & $0,46^{\text {abcd }}$ & 0,23 \\
\hline & 2,5 & $0,25^{\mathrm{gh}}$ & $0,33^{\mathrm{fg}}$ & $0,42^{\text {bcde }}$ & $0,49^{\mathrm{abc}}$ & 0,37 \\
\hline & 5 & $0,34^{\mathrm{efg}}$ & $0,41^{\text {def }}$ & $0,42^{\text {bcde }}$ & $0,46^{\text {abcd }}$ & 0,41 \\
\hline & 10 & $0,39^{\text {def }}$ & $0,50^{\mathrm{ab}}$ & $0,46^{\text {abcd }}$ & $0,54^{\mathrm{a}}$ & 0,47 \\
\hline & Rerata & 0,29 & 0,37 & 0,33 & 0,49 & $(+)$ \\
\hline
\end{tabular}

Keterangan: Angka pada baris dan kolom yang diikuti huruf tidak sama menunjukkan berbeda pada tingkat nyata ( $\alpha$ ) $5 \%$ menurut uji DMRT. (-) tidak terjadi interaksi antar faktor. (+) tidak terjadi interaksi antar faktor.

\section{Jumlah Daun}

Jumlah daun terus bertambah banyak seiiring waktu penelitian. Hasi sidik ragam (anova) menunjukkan bahwa kompos biochar $10 \%$ dan kompos kirinyuh $10 \%$ berinteraksi secara positif $(\mathrm{P}<0.05)$ dalam mempengaruhi jumlah daun pada pengamatan 21 dan 28 HST. Hasil penelitian menunjukkan pada pengamatan jumlah daun 14 HST tidak terjadi interaksi tetapi menunjukkan beda yang nyata antar aras perlakuan. Data tabel 8 menunjukkan bahwa dengan pemberian kompos biochar $10 \%$ cendrung meningkatkan jumlah daun. Faktor tunggal kompos Kerinyuh juga menunjukkan pengaruh yang nyata antar aras perlakuan.

Tabel 8. Jumlah Daun (Helai)

\begin{tabular}{|c|c|c|c|c|c|c|}
\hline \multirow{2}{*}{$\begin{array}{c}\text { Waktu } \\
\text { Pengamatan } \\
\text { (HST) }\end{array}$} & \multirow{2}{*}{$\begin{array}{c}\text { Kompos } \\
\text { Biochar } \\
(\%)\end{array}$} & \multicolumn{4}{|c|}{ Kompos Kirinyuh (\%) } & \multirow[b]{2}{*}{ Rerata } \\
\hline & & 0 & 2,5 & 5 & 10 & \\
\hline \multirow{5}{*}{14} & 0 & 2,17 & 2,67 & 3,00 & 4,00 & $2,96^{\mathrm{b}}$ \\
\hline & 2,5 & 3,33 & 3,50 & 4,00 & 4,17 & $3,75^{\mathrm{a}}$ \\
\hline & 5 & 3,67 & 3,67 & 3,83 & 4,00 & $3,79^{\mathrm{a}}$ \\
\hline & 10 & 4,00 & 3,83 & 3,83 & 4,50 & $4,04^{\mathrm{a}}$ \\
\hline & Rerata & $3,29^{c}$ & $3,42^{b c}$ & $3,67^{\mathrm{b}}$ & $4,17^{\mathrm{a}}$ & $(-)$ \\
\hline \multirow{5}{*}{21} & 0 & $3,33^{\mathrm{f}}$ & $4,00^{\mathrm{ef}}$ & $4,67^{\mathrm{de}}$ & $6,00^{\mathrm{ab}}$ & 4,50 \\
\hline & 2,5 & $5,00^{\mathrm{cd}}$ & $5,50^{\text {bcd }}$ & $5,50^{\mathrm{bcd}}$ & $5,67^{\mathrm{abc}}$ & 5,42 \\
\hline & 5 & $5,67^{\mathrm{abc}}$ & $5,50^{\text {bcd }}$ & $5,83^{\mathrm{abc}}$ & $5,83^{\mathrm{abc}}$ & 5,71 \\
\hline & 10 & $5,83^{\mathrm{abc}}$ & $6,00^{\mathrm{ab}}$ & $6,00^{\mathrm{ab}}$ & $6,50^{\mathrm{a}}$ & 6,08 \\
\hline & Rerata & 4,96 & 5,25 & 5,50 & 6,00 & $(+)$ \\
\hline \multirow{5}{*}{28} & 0 & $3,50^{\mathrm{f}}$ & $5,33^{\mathrm{e}}$ & $6,50^{\mathrm{de}}$ & $8,17^{\mathrm{abc}}$ & 5,88 \\
\hline & 2,5 & $6,17^{\mathrm{de}}$ & $7,33^{\mathrm{cd}}$ & $8,17^{\text {bc }}$ & $8,83^{\mathrm{ab}}$ & 7,63 \\
\hline & 5 & $7,33^{\text {cd }}$ & $7,83^{\text {bc }}$ & $7,83^{\mathrm{bc}}$ & $8,33^{\mathrm{abc}}$ & 7,83 \\
\hline & 10 & $8,17^{\mathrm{abc}}$ & $8,00^{\mathrm{abc}}$ & $8,17^{\mathrm{abc}}$ & $9,17^{\mathrm{a}}$ & 8,38 \\
\hline & Rerata & 6,29 & 7,13 & 7,67 & 8,63 & $(+)$ \\
\hline
\end{tabular}

Keterangan: Angka pada baris dan kolom yang diikuti huruf tidak sama menunjukkan berbeda pada tingkat nyata ( $\alpha$ ) 5\% menurut uji DMRT. (-) tidak terjadi interaksi antar faktor. (+) tidak terjadi interaksi antar faktor.

\section{Luas Daun}

Hasil sidik ragam (Anova) menunjukkan tidak terjadi interaksi antara perlakuan kompos biochar dan kompos Kirinyuh terhadap luas daun. Hasil penelitian menunjukkan bahwa kompos biochar tidak berpengaruh nyata terhadap luas daun. Data tabel 9 menunjukkan bahwa dengan pemberian kompos biochar $10 \%$ cenderung menunjukkan luas daun terluas. Kompos kirinyuh juga tidak menunjukkan pegaruh antar aras perlakuan, tetapi dengan pemberian kompos kirinyuh $10 \%$ meningkatkan luas daun.

\section{Berat Segar dan Kering Tanaman}

Hasil sidik ragam (Anova) menunjukkan bahwa kompos biochar $10 \%$ dan kompos Kirinyuh $10 \%$ berinteraksi secara positif $(\mathrm{P}<0.05)$ dalam mempengaruhi berat segar tanaman. Data tabel 10 menunjukkan tidak terjadi interaksi pada pengamatan berat kering daun tetapi menunjukkan beda nyata antar aras perlakuan. Hasil penelitian menujukkan bahwa dengan pemberian kompos biochar $10 \%$ dan pemberian kompos kirinyuh $10 \%$ cenderung meningkatkan berat kering tanaman.
Tabel 9. Luas Daun (cm)

\begin{tabular}{cccccc}
\hline Kompos & \multicolumn{4}{c}{ Kompos Kirinyuh (\%) } & \multirow{2}{*}{ Rerata } \\
\cline { 2 - 5 } Biochar $(\%)$ & 0 & 2,5 & 5 & 10 & \\
\hline 0 & 12,34 & 59,09 & 56,18 & 97,71 & $56,33^{\text {a }}$ \\
2,5 & 30,25 & 52,32 & 65,35 & 104,33 & $63,06^{\text {a }}$ \\
5 & 81,07 & 62,86 & 83,35 & 54,38 & $70,41^{\text {a }}$ \\
10 & 54,38 & 31,03 & 83,11 & 126,55 & $73,77^{\text {a }}$ \\
\hline Rerata & $44,51^{\text {a }}$ & $51,32^{\text {a }}$ & $72,00^{\text {a }}$ & $95,74^{\text {a }}$ & $(-)$ \\
\hline
\end{tabular}

Keterangan: Angka pada baris dan kolom yang sama diikuti huruf sama menunjukkan tidak berbeda pada tingkat nyata ( $\alpha$ ) $5 \%$ menurut uji DMRT. (-) tidak terjadi interaksi antar faktor.

$\underline{\text { Tabel 10. Berat Segar dan Kering Tanaman (g) }}$

\begin{tabular}{|c|c|c|c|c|c|c|}
\hline \multirow{2}{*}{ Pengamatan } & \multirow{2}{*}{$\begin{array}{c}\text { Kompos } \\
\text { Biochar }(\%)\end{array}$} & \multicolumn{4}{|c|}{ Kompos Kirinyuh (\%) } & \multirow{2}{*}{ Rerata } \\
\hline & & 0 & 2,5 & 5 & 10 & \\
\hline \multirow{5}{*}{ Segar } & 0 & $0,37^{\mathrm{g}}$ & $0,34^{\mathrm{g}}$ & $1,45^{\mathrm{g}}$ & $9,35^{\text {bcd }}$ & 2,88 \\
\hline & 2,5 & $0,98^{\mathrm{g}}$ & $3,55^{\mathrm{fg}}$ & $5,89^{\mathrm{def}}$ & $10,82^{b}$ & 5,31 \\
\hline & 5 & $3,33^{\mathrm{fg}}$ & $5,22^{\mathrm{ef}}$ & $6,42^{\text {cdef }}$ & $9,11^{\text {bcd }}$ & 6,02 \\
\hline & 10 & $5,93^{\text {def }}$ & $10,05^{\mathrm{bc}}$ & $7,97^{\text {bcde }}$ & $19,22^{\mathrm{a}}$ & 10,79 \\
\hline & Rerata & 2,65 & 4,79 & 5,43 & 12,13 & $(+)$ \\
\hline \multirow{5}{*}{ Kering } & 0 & 0,03 & 0,14 & 0,41 & 4,50 & $1,27^{b}$ \\
\hline & 2,5 & 0,19 & 0,89 & 1,36 & 4,63 & $1,77^{\mathrm{b}}$ \\
\hline & 5 & 0,37 & 2,12 & 1,92 & 3,93 & $2,09^{\mathrm{b}}$ \\
\hline & 10 & 2,42 & 3,42 & 3,44 & 5,02 & $3,57^{\mathrm{a}}$ \\
\hline & Rerata & $0,75^{\mathrm{b}}$ & $1,64^{\mathrm{b}}$ & $1,78^{\mathrm{b}}$ & $4,52^{\mathrm{a}}$ & $(-)$ \\
\hline
\end{tabular}

Keterangan: Angka pada baris dan kolom yang diikuti huruf tidak sama menunjukkan berbeda pada tingkat nyata (a) 5\% menurut uji DMRT. (-) tidak terjadi interaksi antar faktor. (+) tidak terjadi interaksi antar faktor.

\section{Panjang Akar}

Hasil sidik ragam (anova) menunjukkan tidak terjadi interaksi antara perlakuan kompos biochar dan kompos Kirinyuh terhadap panjang akar. Hasi penelitian menunjukkan bahwa kompos biochar tidak berpengaruh nyata terhadap panjang akar. Data tabel 11 menunjukkan bahwa dengan pemberian kompos biochar $10 \%$ dan kompos kirinyuh $10 \%$ memeliki akar terpanjang dan akar tependek tedapat pada perlakuan kontrol.

Tabel 11. Panjang Akar (cm)

\begin{tabular}{cccccc}
\hline Kompos & \multicolumn{4}{c}{ Kompos Kirinyuh $(\%)$} & \multirow{2}{*}{ Rerata } \\
\cline { 2 - 5 } Biochar $(\%)$ & 0 & 2,5 & 5 & 10 & \\
\hline 0 & 6,38 & 7,45 & 10,52 & 13,15 & $9,38^{\mathrm{b}}$ \\
2,5 & 10,05 & 11,50 & 12,03 & 13,25 & $11,71^{\mathrm{a}}$ \\
5 & 12,73 & 10,78 & 11,05 & 14,13 & $12,18^{\mathrm{a}}$ \\
10 & $11,27^{\mathrm{y}}$ & 12,45 & 12,18 & 13,17 & $12,27^{\mathrm{a}}$ \\
\hline Rerata & $10,11^{\mathrm{c}}$ & $10,55^{\mathrm{bc}}$ & $11,45^{\mathrm{b}}$ & $13,43^{\mathrm{a}}$ & $(-)$ \\
\hline
\end{tabular}

Keterangan: Angka pada baris dan kolom yang sama diikuti huruf sama menunjukkan tidak berbeda pada tingkat nyata ( $\alpha$ ) $5 \%$ menurut uji DMRT. (-) tidak terjadi interaksi antar faktor.

\section{Berat Segar dan KeringTrubus}

Hasil sidik ragam (anova) menunjukkan bahwa kompos biochar $10 \%$ dan kompos kirinyuh $10 \%$ berinteraksi secara positif $(\mathrm{P}<0.05)$ dalam mempengaruhi berat segar trubus. Data tabel 12 menunjukkan tidak terjadi interaksi pada pengamatan berat kering trubus tetapi menunjukkan beda nyata antar aras perlakuan. Hasil penelitian menunjukkan bahwa dengan pemberian kompos biochar $10 \%$ dan kompos kirinyuh $10 \%$ cenderung meningkatkan berat kering trubus.

$\underline{\text { Tabel 12. Berat Segar dan Kering Trubus (g) }}$

\begin{tabular}{|c|c|c|c|c|c|c|}
\hline \multirow{2}{*}{ Pengamatan } & \multirow{2}{*}{$\begin{array}{c}\text { Kompos } \\
\text { Biochar } \\
(\%)\end{array}$} & \multicolumn{4}{|c|}{ Kompos Kirinyuh (\%) } & \multirow[b]{2}{*}{ Rerata } \\
\hline & & 0 & 2,5 & 5 & 10 & \\
\hline \multirow{5}{*}{ Segar } & 0 & $0,35^{\mathrm{g}}$ & $0,28^{\mathrm{g}}$ & $1,24^{\mathrm{g}}$ & $8,09^{\text {bcd }}$ & 2,49 \\
\hline & 2,5 & $0,86^{\mathrm{g}}$ & $3,11^{\mathrm{fg}}$ & $5,05^{\mathrm{def}}$ & $9,37^{\mathrm{b}}$ & 4,60 \\
\hline & 5 & $2,84^{\mathrm{fg}}$ & $4,52^{\mathrm{ef}}$ & $5,69^{\text {cdef }}$ & $7,97^{\text {bcd }}$ & 5,26 \\
\hline & 10 & $5,10^{\text {bc }}$ & $8,54^{\mathrm{bc}}$ & $6,90^{\text {bcde }}$ & $16,81^{\mathrm{a}}$ & 9,34 \\
\hline & Rerata & 2,29 & 4,11 & 4,72 & 10,56 & $(+)$ \\
\hline \multirow{5}{*}{ Kering } & 0 & 0,02 & 0,13 & 0,40 & 4,29 & $1,21^{\mathrm{b}}$ \\
\hline & 2,5 & 0,17 & 0,82 & 1,29 & 4,49 & $1,69^{b}$ \\
\hline & 5 & 0,29 & 1,98 & 1,85 & 3,78 & $1,97^{\mathrm{b}}$ \\
\hline & 10 & 2,35 & 3,25 & 3,27 & 4,76 & $3,41^{\mathrm{a}}$ \\
\hline & Rerata & $0,71^{\mathrm{b}}$ & $1,54^{\mathrm{b}}$ & $1,70^{\mathrm{b}}$ & $4,33^{\mathrm{a}}$ & $(-)$ \\
\hline
\end{tabular}

Keterangan: Angka pada baris dan kolom diikuti huruf yang sama menunjukkan berbeda pada tingkat nyata ( $\alpha$ ) 5\% menurut uji DMRT. (-) tidak terjadi interaksi antar faktor. (+) tidak terjadi interaksi antar faktor.

\section{Berat Segar dan Karing Akar}

Hasil sidik ragam (anova) menunjukkan tidak terjadi interaksi antara perlakuan kompos biochar dan kompos Kirinyuh terhadap berat segar dan kering akar. Hasil penelitian menunjukkan bahwa kompos biochar berpengaruh nyata terhadap berat segar dan kering akar. Hasil penelitian menunjukkan bahwa dengan pemberian kompos biochar $10 \%$ dan kompos kirinyuh $10 \%$ cenderung meningkatkan berat segar dan kering akar (Tabel 13). 
Tabel 13. Berat Segar dan Kering Akar (cm)

\begin{tabular}{lcccccc}
\hline \multirow{2}{*}{ Pengamatan } & Kompos & \multicolumn{4}{c}{ Kompos Kirinyuh (\%) } & \multirow{2}{*}{ Rerata } \\
\cline { 2 - 6 } Segar & Biochar $(\%)$ & 0 & 2,5 & 5 & 10 & \\
\hline \multirow{4}{*}{ Kering } & 0 & 0,02 & 0,06 & 0,21 & 1,26 & $0,39^{\mathrm{c}}$ \\
& 2,5 & 0,12 & 0,45 & 0,84 & 1,44 & $0,71^{\mathrm{b}}$ \\
& 5 & 0,49 & 0,70 & 0,73 & 1,14 & $0,77^{\mathrm{b}}$ \\
& 10 & 0,83 & 1,51 & 1,07 & 2,41 & $1,46^{\mathrm{a}}$ \\
\cline { 2 - 6 } & Rerata & $0,37^{\mathrm{c}}$ & $0,68^{\mathrm{b}}$ & $0,71^{\mathrm{b}}$ & $1,56^{\mathrm{a}}$ & $(-)$ \\
\hline & 0 & 0,01 & 0,02 & 0,01 & 0,21 & $0,06^{\mathrm{b}}$ \\
& 2,5 & 0,02 & 0,07 & 0,07 & 0,14 & $0,08^{\mathrm{b}}$ \\
& 5 & 0,08 & 0,14 & 0,07 & 0,15 & $0,11^{\mathrm{ab}}$ \\
& 10 & 0,06 & 0,16 & 0,17 & 0,27 & $0,17^{\mathrm{a}}$ \\
\cline { 2 - 6 } & Rerata & $0,04^{\mathrm{b}}$ & $0,10^{\mathrm{b}}$ & $0,08^{\mathrm{b}}$ & $0,19^{\mathrm{a}}$ & $(-)$ \\
\hline
\end{tabular}

Keterangan: Angka pada baris dan kolom diikuti huruf yang tidak sama menunjukkan berbeda pada tingkat nyata ( $\alpha$ ) $5 \%$ menurut uji DMRT. (-) tidak terjadi interaksi antar faktor.

\section{Ratio Tajuk Akar}

Hasil sidik ragam (anova) menunjukkan tidak terjadi interaksi antara perlakuan kompos biochar dan kompos kirinyuh terhadap ratio tajuk akar. Hasil penelitian menunjukkan bahwa kompos biochar tidak berpengaruh nyata terhadap ratio tajuk akar. Hasil penelitian menunjukkan bahwa dengan pemberian kompos biochar $10 \%$ dan kompos kirinyuh $10 \%$ cenderung meningkatkan ratio tajuk akar (Tabel 14).

Tabel 14. Ratio Tajuk Akar

\begin{tabular}{cccccc}
\hline \multirow{2}{*}{ Kompos Biochar (\%) } & \multicolumn{5}{c}{ Kompos Kirinyuh (\%) } \\
\cline { 2 - 5 } & 0 & 2,5 & 5 & 10 & Rerata \\
\hline 0 & 3,33 & 12,33 & 33,00 & 51,78 & $25,11^{\text {a }}$ \\
2,5 & 9,00 & 11,75 & 38,95 & 41,80 & $25,37^{\text {a }}$ \\
5 & 5,16 & 19,52 & 26,23 & 41,26 & $23,04^{\text {a }}$ \\
10 & 101,26 & 22,09 & 20,18 & 17,54 & $40,27^{\text {a }}$ \\
\hline Rerata & $29,69^{\text {a }}$ & $16,42^{\text {a }}$ & $29,59^{\text {a }}$ & $38,10^{\text {a }}$ & $(-)$
\end{tabular}

Keterangan: Angka pada baris dan kolom yang sama diikuti huruf sama menunjukkan tidak berbeda pada tingkat nyata (a) 5\% menurut uji DMRT. (-) tidak terjadi interaksi antar faktor.

\section{Indeks Panen}

Hasil sidik ragam (anova) menunjukkan tidak terjadi interaksi antara perlakuan kompos biochar dan kompos kirinyuh terhadap pengamatan indeks panen.

Tabel 15. Indeks Panen (\%)

\begin{tabular}{cccccc}
\hline Kompos Biochar & \multicolumn{5}{c}{ Kompos Kirinyuh (\%) } \\
\cline { 2 - 5 }$(\%)$ & 0 & 2,5 & 5 & \multirow{2}{*}{ Rerata } \\
\hline 0 & 93,08 & 93,91 & 98,86 & 97,37 & $95,81^{\mathrm{b}}$ \\
2,5 & 97,18 & 97,81 & 98,72 & 98,61 & $98,08^{\mathrm{a}}$ \\
5 & 97,02 & 97,31 & 98,71 & 98,28 & $97,83^{\text {ab }}$ \\
10 & 98,91 & 98,14 & 97,65 & 98,40 & $98,28^{\mathrm{a}}$ \\
\hline Rerata & $96,55^{\mathrm{a}}$ & $96,79^{\mathrm{a}}$ & $98,49^{\mathrm{a}}$ & $98,17^{\mathrm{a}}$ & $(-)$ \\
\hline
\end{tabular}

Keterangan: Angka pada baris dan kolom yang sama diikuti huruf sama menunjukkan tidak berbeda pada tingkat nyata ( $\alpha$ ) $5 \%$ menurut uji DMRT. (-) tidak terjadi interaksi antar faktor.

Hasil penelitian menunjukkan bahwa kompos biochar tidak berpengaruh nyata terhadap indeks panen. hasil penelitian menunjukkan bahwa dengan pemberian kompos biochar $10 \%$ dan kompos kirinyuh $10 \%$ cenderung indeks panen (Tabel 15).

\subsection{Pembahasan}

Hasil sidik ragam (Anova) menunjukkan bahwa pemberian jenis biochar $10 \%$ dan kompos biochar berinteraksi secara positif $(\mathrm{P}<0.05)$ dalam mempengaruhi tinggi tanaman $28 \mathrm{HST}$, dimeter batang $28 \mathrm{HST}$, jumlah daun 21dan 28 HST, berat segar tanaman, berat segar trubus dan panjang akar tanaman bayam. Hasil penelitian menunjukkan bahwa pemberian kompos biochar $10 \%$ dan kompos kirinyuh $10 \%$ yang diamati berpengaruh positif terhadap persen agregasi tanah dimana suhu tanah -1 dan 28 HST meningkat, pH Tanah -1 dan 28 HST mendekati netral, DHL tanah -1 dan 28 HST meningkat, kadar lengas tanah -1 dan 28 HST meningkat dan berat volume tanah -1 dan 28 HST meningkat. Pemberian biochar ke dalam tanah dapat menekan kehilangan nutrient (Laird dkk., 2010a, Singh dkk., 2010, Major dkk., 2012, Liu dkk., 2014), meningkatkan kapasitas tanah mengikat air (Novak dkk., 2009, Laird dkk., 2010), menaikan pH dan meningkatkan kapasitas tukar kation (KTK) tanah (Hossain dkk., 2010, Silber dkk., 2010), meningkatkan populasi dan aktivitas mikroba tanah (Graber dkk., 2010, Kolton dkk., 2010), dan pada gilirannya meningkatkan pertumbuhan tanaman. Disamping itu porositas biochar yang tinggi dapat meningkatkan kemampuan tanah dalam mengikat air sehingga lebih tersedia bagi tanaman dan mahkluk hidup lainnya (Saleh dkk. 2012). Hal ini sependapat dengan (Dariah, dkk. 2013). Pengaruh positif terhadap peningkatan pori tanah tersedia akan berdampak terhadap kemampuan jenis biochar dalam mengairi, yang sangat bermanfaat dalam meningkatkan efisiensi penggunaan air ke dalam tanah. Selanjutnya penelitian (Dariah dkk, 2013) menyatakan bahwa biochar berpengaruh positif terhadap BV (Bulk Density), ruang pori total dan distribusi pori tanah.
Hasil penelitian menunjukkan bahwa kombinasi perlakuan kompos biochar 10\% dan kompos kirinyuh 10\% yang diamati berpengaruh positif terhadap pertumbuhan dan hasil tanaman bayam yang dapat diekspresikan dalam bentuk (tinggi tanaman tertinggi yaitu $15,42 \mathrm{~cm}$, diameter batang terbesar yaitu $0,54 \mathrm{~cm}$, jumlah daun terbanyak yaitu 9,17 helai, berat segar total yaitu 19,22 g, dan berat segar trubus terberat yaitu 16,81 g). Hal ini dikarenakan kombinasi perlakuan kompos biochar $10 \%$ dan kompos Kerinyuh $10 \%$ yang diberikan telah mampu menyediakan unsur hara yang cukup untuk pertumbuhan tanaman bayam. Hal ini sesuai dengan penelitian Sarkar, dkk (2004) pupuk yang mengandung unsur $\mathrm{N}$ dapat mempengaruhi sifat pertumbuhan tanaman secara luas dan membantu pembebasan elemen nutrisi selama periode pertumbuhan tanaman. Kompos kirinyuh tidak hanya menyediakan hara bagi tanaman, tetapi juga mengandung bahan organik yang berperan dalam memperbaiki sifat-sifat tanah. Peranan bahan organik bagi tanah adalah dapat memperbaiki sifat fisik, biologi, dan kimia tanah. Perbaikan sifat fisik tanah berakibat pada aerasi menjadi lebih baik dan meningkatkan daya pegang air, sehingga air tersedia bagi tanaman (Bete, 2018). Aerasi yang baik menyebabkan proses dekomposisi oleh mikroorganisme berjalan baik, dimana mikroorganisme berperan dalam proses perombakan senyawa anorganik menjadi senyawa organik yang dapat diserap tanaman. (Atmojo, 2007).

Penggunaan bahan organik seperti pupuk kompos kirinyuh juga dapat meningkatkan aktifitas mikroorganisme didalam tanah karena memiliki kandungan karbon yang cukup tinggi dimana karbon merupakan sumber energi bagi mikroorganisme tanah. Nugroho (2013) menyatakan bahan organik berfungsi sebagai sumber bahan energi bagi mikroba dan merupakan salah satu komponen tanah yang sangat penting bagi ekosistem tanah, dimana bahan organik merupakan sumber dan pengikat hara dan sebagai substrat bagi mikroba tanah. Hanafiah (2010) juga menyatakan bahwa penambahan bahan organik dapat meningkatkan KTK dan $\mathrm{pH}$ tanah yang berpengaruh tehadap penyerapan hara. Kombinasi pemberian kompos biochar $10 \%$ dan kompos kirinyuh $10 \%$ telah dapat menciptakan medium yang baik bagi pertumbuhan tanaman bayam dimana selain menyediakan ketersediaan hara kombinasi keduanya juga dapat meningkatkan kualitas tanah menjadi lebih baik. Unsur hara dapat terserap dengan baik akibat perbaikan sifat-sifat tanah, sehingga akar dapat menyerap dan mentranslokasikan unsur hara ke seluruh organ tanaman khususnya untuk pertumbuhan tanaman. Hal ini sesuai dengan pernyataan Hakim, dkk. (1989), bahwa ketersediaan unsur hara tanaman tidak terlepas dari kondisi tanah. Kondisi tanah yang baik akan mendukung pertumbuhan awal tanaman. Menurut Harjadi (1991), tanaman akan tumbuh dengan baik apabila unsur hara yang dibutuhkan cukup tersedia dalam bentuk yang dapat diserap oleh tanaman. Pertumbuhan tinggi tanaman terjadi karena adanya proses pembelahan dan perpanjangan sel yang didominasi pada ujung tanaman tersebut serta unsur hara yang menunjang pertumbuhan telah tercukupi seperti N, P dan K. Pertambahan tinggi tanaman merupakan proses fisiologi dimana sel melakukan pembelahan (Lakitan, 2000).

Menurut Lingga dan Marsono (2001) peran N adalah mempercepa pertumbuhan tanaman secara keseluruhan terutama batang dan daun. Tisdale dan Nelson (1975) menyatakan bahwa nitrogen merupakan penyusun utama protein dari sebagian klorofil yang mempunyai peranan penting pada proses fotosintesis. Fotosintat yang dihasilkan dari proses fotosintesis dapat digunakan tanaman untuk proses pembelahan sel, sehingga tanaman bayam yang diamati mengalami peningkatan pertambahan tinggi setiap minggu. Selain itu unsur hara $\mathrm{P}$ berperan dalam pembelahan sel dan perkembangan jaringan tanaman. Menurut Foth (1997) bahwa unsur hara P dibutuhkan tanaman dalam pembelahan sel, apabila kebutuhan unsur hara $\mathrm{P}$ dapat terpenuhi pembelahan sel akan berjalan lancar. Selain unsur N dan P, unsur K juga berperan dalam pertumbuhan tanaman karena unsur K membantu metabolisme karbohidrat dan mempercepat pertumbuhan meristematik (Nyakpa dkk, 1988). Perakaran yang baik dapat mengaktifkan penyerapan unsur hara sehingga metabolisme cepat berlangsung dengan baik. Atmojo (2007), mengemukakan bahwa penambahan bahan organik akan meningkatkan kemampuan menahan air sehingga mampu menyediakan air dalam tanah untuk pertumbuhan tanaman. Peran air sebagai pelarut unsur hara di dalam tanah menyebabkan tanaman dapat dengan mudah mengambil hara tersebut sebagai bahan makanan melalui akar dan sekaligus mengangkut hara tersebut kebagian-bagian tanaman. Sarief (1986) juga menyatakan dengan pemberian bahan organik kedalam tanah dapat meningkatkan berat basah dan berat kering dan secara otomatis akan meningkatkan rasio tajuk dan akar.

Bahan kering tanaman adalah bahan tanaman setelah seluruh air yang terkandung didalamnya dihilangkan. Berat kering merupakan ukuran pertumbuhan dan perkembangan tanaman karena berat kering mencerminkan akumulasi senyawa organik yang berhasil disintesis oleh tanaman. Berat kering menunjukkan perbandingan antara air dan bahan padat yang dikendalikan jaringan tanaman. Menurut Prawiranata dkk, (1995), berat kering tanaman mencerminkan status nutrisi suatu tanaman dan juga merupakan indikator yang menentukan baik tidaknya suatu pertumbuhan dan perkembangan tanaman sehingga erat kaitannya dengan ketersediaan hara. Menurut Gardner dkk (1991) rasio tajuk dan akar sangat dipengaruhi oleh pemupukan $\mathrm{N}$ pada tanaman, unsur hara $\mathrm{N}$ berperan dalam proses fotosintesis yang menghasilkan fotosintat yang digunakan pada pembentukan tajuk dan akar. Pertumbuhan tajuk akan lebih ditingkatkan bila unsur nitrogen dan air lebih banyak. Gradner dkk (1991) juga menambahkan bahwa rasio tajuk dan akar mempunyai pengertian bahwa 
pertumbuhan satu bagian tanaman diikuti dengan pertumbuhan tanaman lainnya, Semakin baik perkembangan akar tanaman maka semakin baik pula perkembangan tajuk tanaman. Rasio tajuk dan akar merupakan faktor penting dalam pertumbuhan tanaman yang mencerminkan kemampuan dalam penyerapan unsur hara serta proses metabolisme yang terjadi pada tanaman.

\section{Simpulan}

Berdasarkan hasil penelitian ini disimpulkan bahwa terjadi interaksi pemberian kompos biochar $10 \%$ dan kompos kirinyu $10 \%$ berpengaruh terhadap tinggi tanaman $28 \mathrm{HST}$, dimeter batang $28 \mathrm{HST}$, jumlah daun 21dan 28 HST, berat segar tanaman, dan berat segar trubus. Kombinasi perlakuan kompos biochar $10 \%$ dan kompos kirinyu $10 \%$ merupakan perlakuan terbaik, yang berbeda nyata dengan kombinasi perlakuan lainnya.

\section{Pustaka}

Asa Mira. 2017. Pemanfaatan Limbah Teh Kompos Sebagai Pengkaya Biochar Dalam Media Pertumbuhan Bayam Cabut (Amaranthus tricolor, L.) Dengan Sistem Tabela. Skripsi. Program Studi Agroteknologi, Fakultas Pertanian, Universitas Timor, Kefamenanu.

Atmojo Suntoro Wongso. 2007. Peranan Bahan Organik Terhadap Kesuburan Murdaningsih dan Y. S. Mbu'u /Buana Sains Vol.14 No 2: 14147 , 2014 Tanah dan Upaya Pengelolannya.

Bete, Hermalinda. 2018. Pengaruh Pemberian Pupuk Cair Kirinyuh (Chromolaena oderata L.) Terhadap pertumbuhan Tanaman Bayam Merah (Amaranthus tricolor L.). Skripsi. Program studi Pendidikan Biologi. Jurusan Pendidikan Matematika dan Ilmu Pengetahuan Alam. Fakultas Keguruan dan Ilmu Pendidikan. Universitas Senata Darma. Yogyakarta.

Dariah A., Sutono N. L. 2013. The effect of biochar on soil quality and maize productivity in upland in dry climate region. 11 th International Conference the East and South East Asia Federation of Soil Science Societies. 21-24 October. Bogor. Indonesia.

Foth, H,D.,and B.G. E.1lis. 1997. Soil Fertility. 2, Boca Raton: Lewis Publisher

Graber E. R., Meller-Harel Y., Kolton M., Cytryn E., Silber A., Rav D. 2010. Biochar impact on development and productivity of pepper and tomato grown in fertigated soilless media.Plant Soil337: 481-496.

Gardner, F. P., R. Pearce dan R. L. Michell 1991. Fisiologi Tanaman Budidaya. Universitas Indonesia Press. Jakarta

Hossain M. K., Strezov V., Chan K. Y., Nelson P. F. 2010.Agronomic properties of wastewater sludge biochar and bioavailability of metals in production of cherry tomato (Lycopersicon esculentum). Chemosphere 78: 1167-1171.

Hanafiah, K.A. 2010. Dasar-dasar Ilmu Tanah. PT. Raja Grafindo Persada Jakarta.

Hakim, N., M. Y. Nyakpa, A. M. Lubis, S.G. Nugroho, M. R. Saul, M. A. Diki, G. B. Hong, H. Bailey. 1986. Dasar-Dasar Ilmu Tanah. Universitas Lampung. Bandar Lampung.

Harjadi. 1991. Pengantar Agronomi. PT Gramedia Pustaka Utama. Jakarta

Kolton M., Meller H. Y., Pasternak Z., Graber E. R., Elad Y., Cytryn E. 2011. Impact of biochar application to soil on the root-associated bacterial community structure of fully developed greenhouse pepper plants.Appl. Environ. Microbiol.77: 4924-4930.

Lakitan B. 2000. Plant Growth Physiology and Development. King Grafindo Persada. Jakarta

Lehmann, J. and S. Joseph. 2009. Biochar for environmental management: an introduction. science and technology. In: Lehmann and Joseph (Eds.). First published by Earthscan in the UK and USA in 2009.

Laird D .A., Fleming P. D., Davis D. D., Horton R., Wang B., Karlen D.L. 2010. Impact of biochar amendments on the quality of a typical Midwestern agricultural soil. Geoderma 158: 443-449.

Liu, L., Shen G., Sun M., Cao X., Shang G., Chen P. 2014. Effect of biochar on nitrous oxide emission and its potential mechanisms. Journal of the Air and Waste Management Association 64:894-902.

Lingga, P, dan Marsono, 2001. Petunjuk Penggunaan Pupuk. Penebar Swadaya.Jakarta.

Major J., Rondon M., Molina D., Riha S. J., Lehmann J. 2012.Nutrient leaching in a Colombian savanna Oxisol amended with biochar. J. Environ. Qual. 41:1076-1086.

Novak J. M., Lima I., Xing B., Gaskin J. W., Steiner C., Das K. C., Ahmedna M. A., Rehrah D.,Watts D.W., Busscher W. J., Schomberg H. 2009. Characterization of designer biochar produced at different temperatures and their effects on a loamy sand. Annal. Environ. Sci. 3:195-206.

Nugroho, Y.A, Sugito Y, Agustina L. 2013. Kajian Penambahan beberapa dosis pupuk hijau dan pengaruhnya terhadap pertumbuhan tanaman selada (Lactuca sativa L). J.Exp. Life Sci. Vol. 3 No. 2, 2013.

Nyakpa, M. Y., A. M. Lubis., M.A. Pulung., Amrah, A. G., A. Munawar., G. B Hong, N. Hakim. 1988.Kesuburan Tanah. Universitas Lampung. Bandar Lampung.
Prawiranata, W, S. Harran dan P. Tjandronegoro. 1995. Dasar Dasar Fisiologi Tumbuhan II. Fakultas Pertanian IPB. Bogor

Rukmana, Rahmat. 2010. Bayam. Penebar Swadaya: Jakarta.

Saleh M. E., Mahmoud A. H., Rashad M. 2012. Peanut biochar as a stable adsorbent for removing NH4-N from wastewater: A preliminary study. Adv. Environ. Biol. 6:2170-2176.

Silber A., Levkovitch I., Graber E. R. 2010. pH-dependent mineral release and surface properties of cornstraw biochar: agronomic implications. Environ. Sci. Technol. 44:9318-9323.

Singh B., Singh B. P., Cowie A. L. 2010. Characterisation and evaluation of biochars for their application as a soil amendment. Aust. J. Soil Sci. 48:516-525

Sarkar, M.A.R., M.Y.A. Pramanik, G.M. Faruk and M.Y. Ali 2004. Effect of green manures and levels of nitrogen on some growth attributes of transplant aman rice. Pakistan Journal of Biological Science. Bangladesh. Dalam Damanik, J. 2009. Pengaruh Pupuk Krinyu (Chromolaena odorata L.) terhadap Pertumbuhan dan Produksi Jagung (Zea mays L.). Skripsi Fakultas Pertanian Universitas Sumatera Utara. Medan. (Tidak dipublikasikan)

Sarief, S. 1986. Kesuburan dan Pemupukan Tanah Pertanian. Pustaka Buana. Bandung

Tisdale, S. Land W. L. Nelson, 1975. Soil fertility and fertililizier. The mac Millan Company, New York

Yuliandry ,W. 2008. Pembuatan dan Manfaat Pupuk Organik. 